\title{
What Makes A Great Preschool Teacher? Best Practices and Classroom Quality in an Urban Early Childhood Setting
}

Charles J. Infurna*

$\begin{array}{ll}\text { Received } & : 28 \text { July } 2020 \\ \text { Revised } & : 28 \text { October } 2020 \\ \text { Accepted } & : 8 \text { December } 2020 \\ \text { DOI } & : 10.26822 / \text { iejee.2021.186 }\end{array}$

"Correspondance Details: Charles J. Infurna. Children's Institute, Department of Clinical and Social Sciences in Psychology, University of Rochester, USA E-mail: cinfurna@childrensinstitute.net ORCID: http://orcid.org/0000-0001-9960-440X

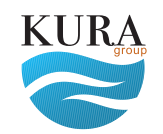

Copyright @ www.iejee.com ISSN: 1307-9298

(C) 2020 Published by KURA Education \& Publishing. This is an open access article under the CC BY- NC- ND license. (https://creativecommons. org/licenses/by/4.0/)

\begin{abstract}
This qualitative study explored preschool teacher beliefs and practices in relationship to observed classroom quality and student outcomes. A phenomenological approach framed the design of the research collected from seven preschool teachers in a large urban school district in Western NY. Teachers were asked two questions about student learning and excellence in teaching. Findings suggest that high performing preschool teachers believe it is important to establish nurturing relationships with their students, foster positive relationships with the families of the children they work with in the classroom, and nurture the socialemotional development of their children in the classroom. Pedagogically, differentiated instruction emerged as a theme in which teachers' described their teaching practice to meet the needs of all their students. Future research should be focused on the impact professional development has on the quality of instruction provided in preschool classrooms.
\end{abstract}

\section{Keywords: \\ Early Childhood Education, Social-Emotional Development, Classroom Quality, Qualitative Study, Preschool Education}

\section{Introduction}

In 2014, approximately one million four-year old children attended one of 40 state-funded preschool programs in the United States (Barnett, Carolan, Fitzgerald, \& Squires, 2012). However, only $30 \%$ of eligible students are enrolled in high quality early childhood education programs (Huang, 2017). Given the recent increases in state and community budgets for early childhood education programming, evidence on the causal effects of preschool are essential in order to justify the continued support for the expansion and improvement of high quality preschool initiatives in the United States. One such problem is the direct relationship between early childhood education classroom quality and student outcomes of universal prekindergarten students (Huang, 2017; Early, Maxwell, Ponder, \& Pan, 2017; Perlman et al., 2016).

High-quality early childhood education experiences help shape and influence children's readiness for school, as well as later life outcomes (Campbell et al., 2012). Similarly, the 
early childhood care landscape has been marked by low quality and inconsistent fidelity in education and care, which has historically been a fiscal burden on local municipalities and communities alike (Barnett et al., 2010). For these reasons, the past two decades have seen greater investments made in the opportunities to provide affordable high-quality early childhood education opportunities that meet stringent national and state regulations through increased amounts of accountability (Bassok, Fitzpatrick, Greenberg, \& Loeb, 2016).

One of the primary goals of state and local initiatives is to improve the quality of early childhood education programming (Early et al., 2017). Empirical research studies conducted over the past two decades have shown that student outcomes are positively associated to high quality early childhood education programming (Broekhuizen, Mokrova, Burchinal, Garrett-Peters, \& The Family Life Project Key Investigators, 2016; Barnett et al., 2012. There is overwhelming support for the developmental importance of high-quality early childhood education settings being predictive of cognitive and socialemotional development in three and four-year old children (Weiland, Ulvestad, Sachs, \& Yoshikawa, 2013).

\section{Literature Review}

A plethora of empirical studies have examined the association between classroom quality and student outcomes (Early et al., 2017; Broekhuizen et al., 2016; Hatfield, Burchinal, Pianta, \& Sideris, 2016; Weiland et al., 2013; Dennis \& O'Connor, 2013). Although theory and research suggest that high-quality early childhood experiences positively influence children's school readiness as they transition to kindergarten (Bassok et al., 2016), the relationship between measures of classroom quality and school readiness are inconsistent in the empirical literature. Contradictory findings exist among studies using the CLASS to measure teacher effectiveness; a measure that is widely regarded as a valid measure of quality in the early childhood education setting.

A widely used classroom quality assessment tool is the Classroom Assessment Scoring System (CLASS; Pianta, La Paro, \& Harme, 2008). The CLASS is made up of three developmental domains; Emotional Support, Classroom Organization, and Instructional Support. The Emotional Support domain measures the emotional connection between teacher and student, teachers' awareness to student academic and/or social-emotional concerns, and the emphasis placed on developmentally appropriate activities that meet the interests of students. The Classroom Organization domain of the CLASS measures how the teacher handles disruptions, how well the classroom functions, and how teachers facilitate activities that stimulate student learning and development. The Instructional Support domain of the CLASS measures how teachers use instructional discussions to foster student higherorder thinking skills, extended conversations between teachers and students, and how teachers facilitate student language development.

The quality of the classroom atmosphere has been measured by two domains of the CLASS, primarily the emotional support and instructional support domains (Mashburn et al., 2008). The emotional support domain measures the extent to which teachers are emotionally engaged with their students. The instructional support domain measures the verbal interactions between a teacher and their students. Teachers who were rated as providing instructionally supportive classroom environments did so by asking open-ended questions, engaging their children in continuous feedback loops, and used scaffolding concepts of instruction (Mashburn et al., 2008; Pianta et al., 2008). Emotional support and the instructional support domains of the CLASS have been associated with student achievement in the empirical research conducted in the United States (Pianta et al., 2008; Pianta, La Paro, Payne, Cox, \& Bradley, 2002; Mashburn et al., 2008).

In a study measuring classroom quality in prekindergarten classrooms, Mashburn et al., (2008) reported that the instructional support domain of the CLASS was positively associated with five measures of student cognitive and language development. In a study examining preschool teacher self-efficacy, classroom quality, and children language and literacy gains, Guo, Piasta, Justice, and Kaderavek (2010) reported that HLM results demonstrated that instructional support $\left(\mu_{02}=1.005, t_{(63)}=1.912, p=.06\right)$ and emotional support $\left(\mu_{02}=1.021, t_{(63)}=1.970, p=.05\right)$ domains of the CLASS exhibited positive trends towards significantly predicting change in children's vocabulary knowledge (Guo et al., 2010). However, Guo and colleagues (2014) reported that neither instructional support $(\mu=1.62, p=.46)$ or emotional support ( $\mu=1.73, p=.41)$ domains of the CLASS significantly predicted change in children's language scores. Similarly, children's literacy scores were not affected by the instructional support $(\mu=.18, p=.93$ ) or emotional support $(\mu=1.96, p=.32)$ domains of the CLASS.

A meta-analysis review conducted by Perlman, Falenchuk, Fletcher, McMullen, Beyene, and Shah (2016) reviewed 35 studies associated with classroom quality and student outcomes. Perlman et al., (2016) reported that no significant associations were found between the Emotional Support domain of the CLASS and student outcomes. However, significant 
but small correlations were found between the Classroom Organization domain of the CLASS and student outcomes. Similarly, the Instructional Support domain of the CLASS was significantly but weakly correlated to the SSRS Social Skills subscale. The relationship between Instructional Support and PPVT, WJ Letter Word ID, and WJ Applied Problems were not significant. Essentially, the connection between classroom teaching observation measures and child growth towards kindergarten readiness is much weaker than the commonly accepted theories of education predict (Bassok et al., 2016; Guo et al., 2014; Guo et al., 2010; Justice, Mashburn, Hamre, \& Pianta, 2008).

The purpose of this study is to determine teachers' working theory about the connection of teaching and learning among UPK teachers based on their pattern of observed classroom quality and growth in child outcomes. Many previous quantitative studies have sought to link child outcomes with classroom quality with mixed results (Huang 2017; Bassok et al., 2016; Perlman et al., 2016; Guo et al., 2014; Son et al., 2013). However, the current gap in empirical research is qualitative studies focused on early childhood educators and their perceptions of student learning (Son et al., 2013). Our proposed study fills the gap in the current literature, with the intention of better identifying the link between child outcomes and classroom quality through the voice of the teachers (Infurna, Riter, \& Schultz, 2018; Mihai et al., 2017; Sherfinski, 2017; Chapman, 2016).

\section{Method}

\section{Setting}

A focus of the Rochester community for the past two decades has been to increase the quality of early childhood education programming. Each year, approximately 3500 three and four-year old children are enrolled in full day early childhood education programming provided by the Rochester City School District, Community Based Organizations (CBO), and Head Start (Infurna et al., 2016). Teachers are tasked with completing cognitive and social-emotional assessments on their children in the fall and spring of the academic year. Early childhood education teachers are also observed each year, with the CLASS assessment serving as an indicator of classroom quality.

RECAP began in 1992 as a collaboration of the United Way of New York State, the Rochester Area Community Foundation, the Rochester City School District (RCSD), the Center for Governmental Research (CGR), Action for a Better Community (ABC), and Children's Institute.
Since its inception, one of RECAP's overall guiding tenets has been to continuously promote, ensure, and improve the quality of pre-k classroom experiences through the use of an integrated and comprehensive information system. Student outcomes and classroom quality have been two of the main tenants of the RECAP project. However, with over two decades of student and classroom data, a significant link between classroom quality and student outcomes has not been able to be made (Infurna et al., 2018; Infurna et al., 2016). For a deeper description of the RECAP project refer to Montes, Weber, Infurna, Van Wagner, Zimmer, and Hightower (2017).

\section{Theoretical framework}

We employed a phenomenological qualitative research approach (Creswell, 2013). The phenomenon in review for the purpose of this study is focused on the link between measured classroom quality and student outcomes at the preschool level. Our aim is to identify processes preschool teachers in an urban school district implement to make meaning of the connection between teaching and learning in preschool.

\section{Participants}

\section{Participant-preschool teachers}

There were a total of seven preschool teachers that participated in this qualitative study. They consisted of four preschool teachers employed by Community Based Organizations (CBOs) and three school based preschool teachers. In total, six preschool teachers were female and all teachers were Caucasian.

\section{Participant-researcher}

Research was conducted from January 2019 to November 2019 by one researcher and three research assistants. Research assistants corresponded to potential participants via email. The research assistants each conducted two interviews. The researcher and lead author conducted one of the interviews.

\section{Data Collection}

Semi-structured interviews consisting of openended questions were conducted between January 2019 and November 2019. Preschool teachers were randomly selected to be contacted to participate in the research study. Teachers that were randomly selected were emailed an outline of the proposed study and a copy of the interview questions. In total, seven preschool teachers participated in the study. Preschool teacher demographic information was collected prior to the interview taking place (see Table 


\section{iejee $\approx$}

1). This study was part of a larger RECAP study in which teachers were asked about the support they receive from their technical support teachers and mentors (teachers and administrators). The responses to those questions were not made part of this qualitative study. To identify a potential link between classroom quality and student cognitive growth and development over the course of the preschool year, additional assessment data was reviewed from a larger on-going longitudinal study (Infurna et al., 2016; Montes et al., 2017). Preschool teacher CLASS (Pianta et al., 2008) outcomes from the 2016-17 academic year was included (see Table 1). The CLASS is a widely implemented classroom quality tool used to measure the quality of early childhood education programming (Perlman et al., 2016). Student data was reviewed to explore the possible connection between teacher responses and student growth over the academic year (see Table 1). The Child Observation Record-Advantage (COR-Advantage; Highscope, 2014) measures eight developmental categories devised of 34 individual items. Preschool teachers collect COR Advantage data at three time points during the academic year (November, March, June). For a more detailed overview of the COR Advantage refer to Wakabayashi, Claxton, \& Smith (2019) and Infurna et al., (2016).

Each research assistant conducted two preschool teacher interviews between January 2019 and June 2019. The lead author conducted one interview in November 2019. Upon receiving consent to participate in study, the research assistants and lead researcher scheduled dates and times for the interviews to be conducted. As part of a larger RECAP qualitative project, only responses from two questions were incorporated in this study; what do you do as a teacher that helps children learn the most?, and what does being a great teacher mean to you? Followup questions were asked to ensure clarification and elaboration of initial responses. All of the interviews were conducted in person at a mutually agreed upon time and location. Each interview was tape recorded. The interviews were then transcribed verbatim.

\section{Data Analysis}

Transcribed interviews resulted in 52 pages of single spaced text. Through repeated and careful examination of the data, common themes and higher order themes emerged (Patton, 2001). The researcher met with the research assistant that conducted the interview to ensure findings were accurate. The researcher and research assistant began developing themes reviewed from the individual transcript. After all seven interviews were conducted, the lead researcher and research assistants carried out a peer debriefing, which included a review of the transcripts and the development of themes. Saturation was reached at the conclusion of reviewing the seventh preschool teacher transcript (Patton, 2001). This process allowed the lead researcher to understand the teacher responses and each individual teacher's perspective on what it is like to be a preschool teacher in an urban school district in Western, NY.

\section{Results}

The findings are presented as a set of four higher order themes. The four higher order themes that emerged were; 1) social-emotional development, 2) establish relationships with families, 3) foster and nurture relationships with students, and 4) differentiate instruction to meet the needs of children.

\section{Social-Emotional Development}

Social-emotional development was a topic discussed in some detail by all seven of the preschool teachers that participated in the study. Several professional development offerings have been provided to preschool teachers in this community over the past three years which focused on trauma informed care and Pyramid Model (Infurna et al., 2018; Hemmeter, Fox, \& Snyder, 2014) training. Teacher 2, a teacher with a very high CLASS score and moderate student CORAdvantage COR said, "The most important aspect, and it's tied to the beginning of my answer, it's the social-emotional piece so that children feel safe,

\section{Table 1}

Teacher Demographic Information

\begin{tabular}{lllcc}
\hline Teacher & Location & Gender & CLASS Score & $\begin{array}{c}\text { COR Advantage } \\
\text { Growth }\end{array}$ \\
\hline Teacher 1 & School Based & Female & 6.9 & 2.3 \\
\hline Teacher 2 & School Based & Female & 6.7 & 1.1 \\
\hline Teacher 3 & School Based & Female & 6.5 & 1.6 \\
\hline Teacher 4 & CBO & Male & 6.5 & 1.6 \\
\hline Teacher 5 & CBO & Female & 6.3 & 1.8 \\
\hline Teacher 6 & CBO & Female & 6.0 & 0.7 \\
\hline Teacher 7 & CBO & Female & 5.1 & 1.5 \\
\hline
\end{tabular}


secure, confident, and competent in their ability to be heard and take care of themselves in the classroom." Similarly, Teacher 6 said, "We're teaching them (students) numbers, but even more so social-emotional skills so what we're doing is teaching them how to share, how to solve a problem." Likewise, Teacher 4 said, "There's a lot of significance in the classroom ecosystem and the relationship between teacher and student...working on building social-emotional skills and how to navigate conflict."

Conflict resolution was discussed in a similar fashion as social-emotional development. A facet of the Highscope curriculum (Highscope, 2014) that is embedded for preschool teachers is a series of activities and lessons focused on conflict management. When the preschool teachers made reference to the importance of social-emotional development, it was followed-up with an idea about managing conflict in the classroom. Teacher 4 said, "We are working on friendship skills, working on how to negotiate conflict, and learning how to be a kind person in our classroom." Teacher 1, a school based teacher with an exemplary CLASS score and high student growth as measured by the COR-Advantage said, "We have a cozy cube area in our classroom. If we didn't have a cozy cube, we would have three children in our classroom that would not be where they currently are socially and emotionally. It is a place for them to cool off." For reference, a cozy cube area is an area of the classroom in which child are able to move to in order to self-regulate their emotions when they feel they need to cool off or relax. As part of the Highscope (2014) curriculum, preschool programs are encouraged to provide space in each classroom in which a child is able to move to in order to regulate their emotions. When asked about social-emotional strategies, Teacher 6 said, "So we're teaching them to try and solve their problems by themselves. So they also know that let's say two kids are crying over a toy, I approach them (the kids) and review the six steps of conflict resolution with them." Similarly, Teacher 4 said, "So much social and emotional growth is happening in the preschool year. I do a lot of work focusing on the development of self-worth and selfrespect. Working on building concepts of self-esteem and empowerment, empowering students to think critically and be in control."

The Pyramid Model (Hemmeter et al., 2014) provides early childhood education teachers with strategies that they can implement when discussing socialemotionally learning. When asked a follow-up question about social-emotional learning, Teacher 5, a community based preschool teacher with a high CLASS score and high student growth as measured by the COR-Advantage said, "I have a lot of social stories I use. Especially at the beginning of the year, we talk a lot about how to be a super friend, different super powers we have, and how if someone takes a toy from you, do we just grab it? And we do, we act stuff out." Teacher 4 said, "I think there's so many other ways engaging in meaningful conflict resolution, engaging in other levels of that self-esteem component, that development of the self-component." He continued, "Again, talking about differences but having...I find a lot of importance in having honest conversations with my kids." Teacher 2 talked about research-based practices when discussing social-emotional learning. She said, "Helping children's social-emotional development, that's a mistake in behavior in that child. Just like you would teach the child how to spell their name and the letters in their name, you would teach that child on how best to communicate what it is they want."

\section{Establish Relationships With Families}

Although a formal question about establishing relationships with families was not included in the interview protocol, it was a talking point for all seven teachers that participated in the study. When asked about what it means to be a great teacher, all the participants made a reference to the importance of establishing positive relationships with the families of the children in their classroom. Teacher 3, a school based teacher with a high CLASS score and high student growth as measured by the COR-Advantage said, "Being a good teacher is somebody who's a team player...you've got parents and families that you need to work together for the success of each child." She continued, "I think understanding the whole family dynamics, and then being able to take that information and actually gear it toward the child, would be helpful in their learning." Teacher 4 said, "Of course academics are important and...the ability to help students grow academically also is based in having strong relationships with them. Of course that extends to strong relationships with families as a part of that team."

The implementation of technology is a strategy that one teacher discussed when developing relationships with families. When asked about building rapport with families, Teacher 5 said, "I use an app called Seesaw. I post pictures of the kids. I pretty much write what we're doing every week, what we did that week." Another strategy a teacher shared was to be an active listener when parents meet with you. Teacher 3 said, "When my school families come in and visit, try and have an open dialogue with your families. Try to keep it light, and when you can see somebody's really hurting, ask them if they would like to talk. You can step aside and be a listening ear." Another way a teacher helps develop a positive working relationship with families of his students is by communicating with them in their native language. Teacher 4 said, "I just took a Spanish class at MCC this past semester, because I have some 
Spanish speaking families and I think it's important to be able to talk to Grandma when she picks up."

\section{Foster and Nurture Relationships with Students}

When initially asked what being a great teacher meant to them, most of the preschool teachers that participated in this study made reference to fostering and developing relationships with the children in their classroom. Teacher 2 said, "First of all, it means being present for your children. It means knowing your children. So, knowing their needs, their learning styles, their interests." She continued, "First and foremost is having a relationship and building trust with your children, your students to let them know that that when they are with you, they're number one, they're safe." Teacher 3 continued, "I think probably looking at each child individually, particularly in pre-k, each child is coming in totally different than each...Every child is different that comes in." Similarly, Teacher 5 said, "I think it's just getting to really know your kids and just building a relationship with them. For me personally, I don't feel like we can really get into the academics until I really know my kids."

Looking from a broader classroom perspective, Teacher 4, a male community based teacher with a high CLASS score and high student growth as measured by the COR-Advantage said, "I think really...part of being a great teacher is an ability to connect individually with of your students, forming a special bond, then also as a whole group, as a whole classroom community." She continued, "I have 17 individual relationships with our class as a unit. I think those relationships are kind of paramount in the ability to then...do teaching." Teacher 6 also has a similar perspective as building community within her classroom. She said, "You know building relationships with them and they build relationships with each other because you can see like now once we go they give each other hugs and say hi, when they come in they're all excited. They made friends. That's great." Teacher 7 said, "Making a positive impact on someone. Being there for them. Oh gosh, I don't feel like...there's so many words. It's just everything that a teacher is, you know. You're their friend, their caretaker, their person that listens to them, that guides them."

Another teacher shared some strategies in which she helps establish and build relationships with kids. Teacher 1 said, "They're used to being heard, but not really listened to." When asked about a specific strategy she implemented about ways she listens, Teacher 1 said, "They're not used to the language coming back to them and taking them further when they have a problem. They're usually used to maybe more louder voices, so they don't understand the difference between; that I'm not angry, I'm trying to help you solve your problem." She continues, "Once you start actively listening, they realize you're hearing them and you're listening to them." Teacher 6 summed it up by stating, "It's really important to show that you care because they need to know you care about them."

\section{Differentiate Instruction to Meet the Needs of Children}

As is similar to the other three higher-order themes, all seven preschool teachers shared ways in which they were able to differentiate their instruction to meet the needs of their children. When asked how she differentiated instruction in her classroom, Teacher 1 shared an example of meeting the unique needs of two children in her classroom. Teacher 1 said, "I have two children with no language skills at all; no articulation. One had just grunts, one is self-mute. I immediately teach sign language and we do colors, which helps them learn very quickly. We spend a bit more time in large group, which is singing and learning through songs and movement, which also helps them." Teacher 7, a community based teacher with a moderate CLASS score and high student growth as measured by the COR-Advantage also gave some examples of how she differentiates instruction throughout the day. At the sand table, Teacher 7 said, "We're playing in the sand table and showing them what an A looks like." At snack time, Teacher 7 said, "When we eat an apple at snack, what does apple start with? A, so it's not just standing up there and singing the alphabet, but it's modeling throughout the entire day as to what that is, what it looks like, what else it could be. That kind of stuff." A different example of differentiated instruction was shared by Teacher 5. Teacher 5 said, "I think. I try really hard to spend at least a little one-onone time with each one of them (students)." Teacher 5 continues, "I do a lot of books in the classroom, where we make books as a class and then we put them out together, so they can read them. So, we may spend a whole week on the same book, but each child is different and it takes some more time to understand." Similarly, Teacher 2 spoke at great length about differentiating her activities focused on reading. Her example was about Three Billy Goats Gruff. She said, "There are so many aspects of that. The children did dramatic play to build comprehension. We pulled out a bridge. They reenacted the story and they took turns doing that. Making bridges with materials, how can you make a bridge?"

Engagement was another strategy shared by a couple of the teachers. Teacher 2 said, "Also, when it comes to their interest, it's making sure that lessons, learning, activities and materials in the classroom are things that they're interested in so that they will 
engage when it's time to." Teacher 2 continues, "For example in the music and movement, how do you want to move? Or I always ask the children, it's their choice on the way that they want to move to maybe go wash their hands. They may not want to go wash their hands, but if they have the choice to make it creative, they will be more engaged and willing to." Teacher 2 also shared how she differentiates in Math and Science. She said, "And then when the grass seed grows, tying that to Math, it's Science, but tying it to Math, measurement. And then they can cut it. And then in a week, it's going to be longer and what do you predict what's going to happen?"

A different strategy that was incorporated by the preschool teachers was that of using open-ended questions. Teacher 6 said, "Instead of giving them closed end questions you're giving them open ended questions so that helps spur their creativity and imagination." Teacher 1 went into great detail about differentiating instruction when she discussed fiction and non-fiction books. She said, "We'll stay now with non-fiction and fiction for the remainder of the year. Which, you asked how we differentiate and how the teacher...that's intentional teaching. Everything I do has more than one objective." Teacher 1 continued, "Yes, I introduced non-fiction, but I also gave them a comparison of what fiction is to non-fiction, how we turn the pages; fine motor, how we look at it, the index."

\section{Discussion}

The purpose of this study was to determine the working theory about the connection of teaching and learning among UPK teachers based on their pattern of observed classroom quality and growth in child outcomes. Overall, seven preschool teachers from a large urban school district in New York State were interviewed. Semi-structured interviews were conducted to illicit preschool teacher thoughts about student learning during the preschool year. The results from this qualitative study suggest that participants believed developing relationships with families, relationships with families, differentiating instruction, and focusing on the social-emotional development of preschool children are critical in ensuring they make positive growth during the preschool year which in turn can lead to a greater opportunity to successfully transition to kindergarten.

\section{Social-Emotional Development}

Throughout the course of the academic year, preschool teachers are offered a wide variety of professional development offerings focused on social- emotional growth and development (Infurna et al., 2016). In recent years, the Rochester community has adopted the Pyramid Model as a means for providing professional support to classroom teachers (Hemmeter et al., 2014). The Pyramid Model consists of three phases of implementation, broken down into three modules. Most recently, teachers in the Rochester community were able to participate in all three phases of the Pyramid Model. It was observed that student socialemotional growth as observed by their classroom teachers grew more than that of their peers in which their classroom teacher did not participate in all three phases of training (Infurna et al., 2016).

Previous empirical studies have focused on the effectiveness of clear policies for responding to children with challenging behaviors, as well as evidence-based practices that reduce challenging behaviors in preschool children (Snyder, Hemmeter, \& Fox, 2015; Sutherland, Conroy, Vo, \& Ladwig, 2014; Kretlow \& Bartholomew, 2010). In order to gain the essential response skills, teachers learn developmentally appropriate practices (DAP) and effective response strategies through professional development sessions. In the Rochester community, DAP over the recent years have been focused on enhancing the social-emotional development of children in pre-k programming (Infurna et al., 2018; 2016). The implementation of professional learning opportunities in Rochester has provided evidence that classroom teachers are incorporating practices learned from the Pyramid Model, which is reflected in student social-emotional growth measured throughout the course of the academic year (Infurna et al., 2016). Short-term training, often knowledge or technique based, is the most common form of inservice training with substantial various in nature and quality, with virtually no evidence of effectiveness (Birman, Desimone, Porter, and Garet, 2000). It is encouraged that the Rochester community continue to offer professional learning opportunities that not only meet the needs of the classroom staff, but also offer on-going professional learning opportunities that will assist classroom teachers in providing welcoming and nurturing environments for their children that will stimulate cognitive growth and social-emotional wellbeing.

\section{Establish Relationships with Families}

A critical component to ensuring the success of the children in your classroom is to ensure a quality relationship with the family of the child as well (Infurna et al., 2018). The classroom teachers interviewed for this study spoke at length about the importance of developing quality relationships with the families of 
the children in their classroom. The preschool time offered to children is both critical and important in establishing routines and enhancing the development of skills, however bridging learning to the home environment is just as critical (Nitecki, 2015). As a shift to more formalized preschool offerings are provided to families across the country, meaningful relationships between families and schools begin to take shape (Nitecki, 2015; Downer \& Meyers, 2010).

Teachers that participated in this study made great lengths in bridging the gap with learning both in the classroom and at home by developing meaningful relationships with families. Parental involvement early on in their child's educational journey has been linked to greater success for the child in the elementary setting (Jeynes, 2014). Similarly, the goal of achieving meaningful family involvement in the preschool setting has been challenging, but the teachers that participated in this study were able to break down potential barriers that could have negatively impacted the development of the teacher-family relationship (McNeal, 2014). One way in which teachers developed meaningful relationships was by taking an interest in learning more about the families' culture. As stated by one teacher, they took it upon themselves to take formal college courses in another language in order to better be able to communicate with family members when visiting their classroom or when the teacher needed to communicate with the family member during home visits and phone calls. It will be important for center and program directors to allow their teachers such opportunities as a willingness for their teachers to take formal courses to better be able to communicate with and enhance their relationship with their families.

Taken as a whole, research suggests that students have greater opportunities for success in school settings when their families are involved in the educational process (Nitecki, 2015). Epstein (2010) has suggested that a new conception of a family's role in the development of their child has evolved from previously limited parental involvement within the school setting, to one now more focused on a comprehensive model of family involvement, even within preschool aged settings. It is critical for classroom teachers to bridge this gap by offering families more opportunities and involvement in the educational development of their families. Evidence from this study suggests that teachers be open, welcoming, and willing to go above and beyond to ensure their families are offered many opportunities throughout the course of the school year to be a part of their children's educational development within the classroom setting (Epstein, 2010).

\section{Foster and Nurture Relationships with Students}

The quality of relationship that forms between a teacher and their students is key to fostering and nurturing both successful instruction and learning in the classroom (Newberry, 2010). Teachers that participated in this study understood that in order to see student growth in a pre-k classroom over the course of the academic year was to get to know their students, meet their unique needs, and create an environment conducive to quality learning and engagement. The way in which the teachers in this study engaged with their students to foster quality relationships is supported by other empirical work. Reeve (2006) found that four characteristics are required to be possessed by teachers in order to aid in their quest to enhance their relationships with their students. Those traits are, a) being in tune with what might be occurring in their lives, b) being able to relate to their students, c) a sense of supportiveness, and d) classroom management.

The current empirical literature suggests that the relationship between a teacher and their students has a remarkable effect on student achievement in the classroom and in other areas of their lives (Pianta \& Stuhlman, 2004). Reeve (2006) has suggested that teachers that exhibit and demonstrate more support within their classroom are better able to engage their students. In the preschool setting, those interactions can be measured by CLASS.

Shortly after the publication of the CLASS (Pianta et al., 2008), early childhood educators, policy makers, directors, and administrators in the Rochester community made the collaborative decision to begin a gradual implementation of the CLASS (Infurna et al., 2016). A primary interest of the community was to better be able to gauge teacher-child interactions in the classroom. Having already established the ECERS as a tool to monitor program quality specific to materials, physical conditions, and input from families (Montes et al., 2017), the CLASS would serve to better monitor classroom quality observed to better be able to serve the cognitive development of preschool age students in the Rochester community.

Pianta and colleagues (2008) reported that the instructional support domain of the CLASS was developed to monitor teacher-child interactions in the classroom. Previous studies have reported evidence of high classroom quality permeating from within the Rochester community (Infurna et al., 2018; Montes et al., 2017). The teachers that participated in this study had relatively high CLASS outcomes (see Table 1) compared to national averages (Infurna et al., 2016). The teachers in this study suggested that getting to 
know their students was beneficial and helpful with regards to helping students learn, grow, and develop in their classrooms (Reeve, 2006). Similarly, the emotional responses between teacher and student are critical in enhancing the teacher-child relationship in the classroom. Newberry and Davis (2008) suggested that the emotional responses between teachers and students also sets forth a pattern of either positive or negative interactions in the classroom. As measured by the emotional support domain of the CLASS, the teachers that participated in this study clearly have mastered the emotional component required for positive cognitive growth of children in a pre-k classroom (Infurna et al., 2018; 2016).

\section{Differentiate Instruction to Meet the Needs of Children}

The majority of preschool teachers that participated in this study spent a great deal of time discussing how they differentiate their instruction throughout the course of the school day. They spoke at great length about their attention to detail and thoughtfulness when preparing activities that would meet the specific needs of their children. Purcell and Rosemary (2008) argue that effective planning, which takes into consideration the unique needs of young children, is critically important to facilitate growth in young children. It is interesting to note that the teachers whose students grew the most throughout the course of the school year based on the COR (HighScope, 2014) and had very high CLASS (Infurna et al., 2016) scores (see Table 1) spent the more time-sharing detailed examples of how they differentiate their instruction. The classroom teachers in this study are offered a plentiful amount of professional development opportunities focused on differentiated instruction and meeting the needs of their children. Despite those opportunities for professional learning, it is evident by the student growth exhibited in these classrooms that children received similar instruction over the course of the academic year (Vlachou \& Fyssa, 2016). The teachers gave specific examples about their instruction and meeting the specific needs of their students. Students did not make as many gains over the course of the school year in classrooms in which the preschool teacher did not give specific examples of how they differentiated their instruction. They spoke about the need to meet their children where they are, but they did not follow-up with examples about how they do so.

Although limited, early childhood education research and the implementation of differentiated instruction has provided positive results (Strogilos, Avramidis, Voulagka, \& Tragoulia, 2018). Recently, work conducted by Gettinger and Stoiber (2012) found that classroom teachers that incorporated differentiated instruction strategies in preschool classrooms found evidence of higher performance on early literacy assessments compared to students in classrooms in which differentiated instruction was not part of the curriculum. In Head Start classrooms, the promotion of early academic skills within the differentiated instruction framework found that high-risk preschool students made significant gains on their early vocabulary assessments compared to their peers that did have the differentiated instruction model implemented in their classroom (De Baryshe, Gorecki, \& Mishima-Young, 2009). Similarly, in our study, Teacher 5, Teacher 1, and Teacher 2 gave very specific examples about how they differentiate instruction in their classroom. The remaining four teachers did not give as many detailed examples specifically about how they differentiate their instruction. The potential positive link between student outcomes and classroom quality may come down to how well preschool teachers are able to articulate what they exactly do in the classroom to meet the unique and specific needs of their children.

It is also interesting to note that professional development opportunities were discussed by some of the preschool teachers that participated in this study. The school district in which the preschool students are educated spends a great amount of time and resources providing professional learning opportunities for preschool teachers. Professional development offerings are provided each month over the course of the academic year. Some of the types of professional offerings included are focused on classroom quality (specific to the CLASS), language and literacy, the HighScope (2014) curriculum, and Math. Research conducted by Catlett (2009) and Fukkink and Lont (2007) reported that professional learning opportunities for teachers are most successful when; (1) is intensive and on-going, (2) includes a sequence of active learning experiences that build on each other, (3) emphasizes specific skills and goals rather than general ones, (4) provides opportunities for application and practice of newly acquired knowledge and skills, and (5) incorporates feedback as well as reflection and self-assessment. Similarly, Catlett (2009) reported that successful professional development programs provide teachers with recommendations for researchbased practices that encourage teachers to set their own goals and engagement in self-reflection throughout the process. Providing teachers with instructional resources that are useful and accessible increase the likelihood of sustainability and fidelity to the professional development approach. Although research suggests that focused professional learning opportunities for teachers are critical, teachers participating in this study are not mandated to attend any specific offerings. Rather, New York State 
mandates that preschool teachers participate in at least 24 hours of professional learning opportunities throughout the course of the academic year (NYSED, 2020). However, New York State does not mandate what types of offerings teachers are required to participate in. When asked what types of support their administration provided, only a few teachers discussed professional learning opportunities.

Again, similar to providing specific examples about differentiating instruction, Teacher 1 and Teacher 5 went into great detail about how professional development has helped them become more effective preschool teachers. Teacher 1 said, "Yes, it's always available. I have a goal of my own every year for what I'm trying to bring to a different higher level. One year it was working with children of trauma. Anything I could take." She continued, "Then another year it was more about working at this (preschool) academic level; what should it look like? What should it feel like? What should my role be?" Teacher 5 added, "We've had a lot of trainings. A lot of our trainings are on that social-emotional piece. At first I was skeptical, but then I'm like, you know what, let me just try it. And I tried it and it really...the last few years, it's really made a huge difference in the classroom." Teacher 3, whose students grew a great deal during the course of the academic year, took professional development in a different direction. Teacher 3 said, "I've been in this district a very long time, so years ago, we had a system set up that was for professional development where we met with colleagues in a very confidential basis." She continued, "You could actually share ideas, share challenges, share in a very non-judgmental format, and you learned a ton of actually strategies from your peers. I think that the collegial support setting was the most important." The other teachers referenced professional development, but they didn't give specific examples of how the professional learning assisted them in their instruction.

\section{Conclusion}

The results from this qualitative study are promising for a few important reasons. First, a majority of the preschool teacher participants expressed the importance of developing and fostering positive relationships with the families of the children in their classroom. Suggestions for practitioners would be to continue to incorporate the four traits of teacher-child relationship enhancement suggested by Reeve (2006) that would give teachers research-based prompts to enhance their relationships with their students. Preschool teachers understand the relationship between families and teachers is critical and vital in ensuring the success of children, but failed to mention any support they receive on how to develop and foster those relationships. Future research should focus on the relationship between teachers and families and how that relationship may affect the cognitive and social-emotional outcomes of their children in the classroom.

Second, only a few of the participants discussed detailed thoughts about professional learning opportunities and how they are able to apply what they learned to their daily instruction. It is encouraging to note that teachers in which their students grew a great deal throughout the course of the academic year shared specific professional learning opportunities. It is encouraged that preschool teachers attend and participate in professional learning opportunities focused on student cognitive and social-emotional development and growth. More specifically, educators should plan on attending professional learning opportunities that build upon each other, scaffold development, and are offered sequentially throughout the course of the academic year (Catlett, 2009; Fukkink \& Lont 2007). Future research should be focused on the relationship between professional development, classroom quality, and student outcomes. It would be interesting to investigate the relationship between the quantity of professional development hours/trainings and classroom quality and student outcomes. Teachers in this school district are able to choose professional development offerings at their leisure, however it would be interesting to investigate how specific trainings/offerings presented in sequential order may affect classroom quality at the preschool level.

Finally, all of the participants in this study made some reference to the importance of the social-emotional development of their children during the academic year. References to social-emotional development came in accordance with developing positive relationships with the children in their classroom. However, detailed responses of social-emotional learning were given by only a few participants. Practitioners in the field of early childhood education would benefit from infusing applications shared within the Pyramid Model and developmentally appropriate practices associated with children that may be experiencing trauma in the classroom (Snyder, Hemmeter, \& Fox, 2015; Hemmeter et al., 2014). It would be interesting to investigate preschool teacher perceived self-efficacy and the potential relationship with social-emotional growth of preschool children before they transition to kindergarten.

\section{Limitations}

This research study did have some limitations. First, only one male teacher volunteered to participate in this study. Throughout the early childhood education field, male teachers are seldom found in these settings. 
Future qualitative studies should try to incorporate the voice of the male early childhood teacher. They (the male teacher) may be able to share their thoughts on early childhood education from a perspective that differs from a female early childhood educator. Second, only teachers employed by and working within one large urban school district participated in this study. Future qualitative preschool studies should incorporate the voice of teachers employed by rural and suburban school districts.

\section{Acknowledgments}

This project would not have been made possible without financial support received from the Konar Foundation-grant \#1831

\section{References}

Barnett, W. S., Epstein, D. J., Carolan, M. E., Fitzgerald, J., Ackerman, D. J., \& Friedman, A. H. (2010). The state of preschool 2010. New Brunswick, NJ: The National Institute for Early Education Research Supported by The Pew Charitable Trusts.

Bassok, D., Fitzpatrick, M., Greenberg, E., \& Loeb, S. (2016). Within and between sector quality differences in early childhood education and care. Child Development, 87(5), 1627-1645.

Birman, B. F., Desimone, L., Porter, A. C., \& Garet, M. S. (2000). Designing professional development that works. Educational Leadership, 57(8), 1-8.

Campbell, F. A., Pungello, E. P., Burchinal, M., Kainz, K., Pan, Y., Wasik, B. H., . . Ramey, C. T. (2012). Adult outcomes as a function of an early childhood educational program: An Abecedarian Project follow-up. Developmental Psychology, 48, 1033.

Catlett, C. (2009). Supporting inclusion through new approaches to professional development. Impact: Feature Issue on Early Childhood Education and Children with Disabilities, 22, 2-3.

Chapman, R. (2016). A case study of gendered play in preschools: How early childhood educators' perceptions of gender influence children's play. Early Child Development and Care, 186(8), 12711284.

Creswell, J. W. (2013). Qualitative inquiry \& research design: Choosing among five approaches. SAGE.
Curby, T. W., LoCasale-Crouch, J., Konold, T. R., Pianta, R. C., Howes, C., Burchinal, M., et al. (2009). The relations of observed classroom Pre-K classroom quality profiles to children's achievement and social competence. Early Education \& Development, 20, 346-372.

DeBaryshe, B. D., Gorecki, D. M., \& Mishima-Young, L. N. (2009). Differentiated instruction to support high-risk preschool learners. NHSA Dialog, 12(3), 227-244.

Downer, J. T., \& Myers, S. S. (2010). Application of a developmental/ecological model to schoolfamily partnerships. Handbook of school-family partnerships, 3-29. New York, NY: Routledge.

Early, D. M., Maxwell, K. L., Burchinal, M., Alva, S., Bender, R. H., Bryant, D., Cai, K., Clifford, R. M., Ebanks, C., ... Pianta, R. C., Vandergrift, N., \& Zill, N. (2007). Teachers' education, classroom quality, and young children's academic skills: Results from seven studies of preschool programs. Child Development, 78(2), 558-580.

Epstein, J. L. (2010). School/family/community partnerships: Caring for the children we share. Phi Delta Kappan, 92(3), 81-96.

Fukkink, R. G., \& Lont, A. (2007). Does training matter? A meta-analysis and review of caregiver training studies. Early Childhood Research Quarterly, 22, 294-311.

Gettinger, M., \& Stoiber, K. C. (2012). Curriculum-based early literacy assessment and differentiated instruction with high-risk preschoolers. Reading Psychology, 33(1-2), 11-46.

Guo, Y., Connor, C. M., Yang, Y., Roehrig, A. D., \& Morrison, F. J. (2012a). The effects of teacher qualification, teacher self-efficacy, and classroom practices on fifth graders' literacy outcomes. The Elementary School Journal, 113(1), 3-24.

Guo, Y., Justice, L. M., Kaderavek, J. N., \& McGinty, A. (2012b). The literacy environment of preschool classrooms: contributions to children's emergent literacy growth. Journal of Research in Reading 35(3), 308-327.

Hatfield, B. E., Burchinal, M. R., Pianta, R. C., \& Sideris, J. (2016). Thresholds in the association between quality of teacher-child interactions and preschool children's school readiness. Early Childhood Research Quarterly, 36, 561-571. 
Hemmeter, M. L., Fox, L., \& Snyder, P. (2014). Teaching Pyramid Observation Tool-Research edition manual. Brookes.

Highscope Educational Research Foundation. (2014). COR Advantage 1.5: Scoring guide. Ypsilanti, MI: HighScope Press.

Huang, F. L. (2017). Does attending a state-funded preschool program improve letter name knowledge? Early Childhood Research Quarterly, 38, 116-126.

Infurna, C. J., Riter, D., \& Schultz, S. (2018). Factors that Determine Preschool Teacher Self-Efficacy in an Urban School District. International Electronic Journal of Elementary Education, 11(1), 1-7.

Infurna, C.J., Hightower, A.D., Van Wagner, G., Strano, L., Lotyczewski, B.S., Montes, G., MacGowan, A., Dangler, P., Hooper, R., Boyle, R., Lubecki, L., Embt, K., \& Breitung, D. (2016). Rochester Early Childhood Assessment Partnership 2015-2016 nineteenth annual report. Children's Institute Technical Report T17-001.

Jeynes, W. H. (2014). Parental involvement that works... because it's age-appropriate. Kappa Delta Pi Record, 50(2), 85-88.

Justice, L. M., Mashburn, A. J., Hamre, B. K., \& Pianta, R. C. (2008). Quality of language and literacy instruction in preschool classrooms serving atrisk pupils. Early Childhood Research Quarterly, 23, 51-68.

Kretlow, A. G., \& Bartholomew, C. C. (2010). Using coaching to improve the fidelity of evidencebased practices: A review of studies. Teacher Education and Special Education, 33(4), 279-299.

Mashburn, A. J., Pianta, R. C., Hamre, B. K., Downer, J. T., Barbarin, O. A., Bryant, D., Burchinal, M., Early, D. M., \& Howes, C. (2008). Measures of classroom quality in prekindergarten and children's development of academic, language, and social skills. Child Development, 79(3) 732-749.

McNeal, R. B. (2014, May). Parent involvement and school performance: The influence of school context. Educational Research for Policy and Practice, 14, 153-167.

Mihai, A., Butera, G., \& Friesen, A. (2017). Examining the use of curriculum to support early literacy instruction: A multiple case study of head start teachers. Early Education and Development, 28(3), 323-343.
Montes, G., Weber, M. R., Infurna, C., Van Wagner, G., Zimmer, A., \& Hightower, A. D. (2017). Factor structure of the ECERS-3 in an urban setting: An independent, brief report. European Early Childhood Education Research Journal, 26(6), 972-984.

Newberry, M., \& Davis, H. (2008). The role of elementary teachers' conceptions of closeness to students on their differential behavior in the classroom. Teaching and Teacher Education, 24, 1965-1985.

Newberry, M. (2010). Identified phases in the building and maintaining of positive teacher- student relationships. Teaching and Teacher Education, $26,1695-1703$.

New York State Education Department, (2020). Early Learning Standards. http://www.p12.nysed.gov/ earlylearning/standards/

Nitecki, E. (2015). Integrated school-family partnerships in preschool: Building quality involvement through multidimensional relationships. School Community Journal, 25(2), 195-219.

Patton, M. Q. (2001). Qualitative evaluation and research methods. 3rd ed. Beverly Hills, CA: Sage.

Purcell, T., \& Rosemary, C. A. (2007). Differentiating instruction in the preschool classroom. In: Justice LM, Teale WH, Vukelich C, Han M, editors. Achieving excellence in preschool literacy instruction. New York: Guilford; 2007. pp. 221-241

Perlman M., Falenchuk O., Fletcher B., McMullen E., Beyene J.,\& Shah, P.S. (2016). A Systematic Review and Meta-Analysis of a Measure of Staff/Child Interaction Quality (the Classroom Assessment Scoring System) in Early Childhood Education and Care Settings and Child Outcomes. PLOS ONE11(12). e0167660. https://doi.org/10.1371/ journal.pone.016766

Pianta, R. C., La Paro, K. M., Payne, C., Cox, M. J., \& Bradley, R. (2002). The relation of kindergarten classroom environment to teacher, family, and school characteristics and child outcomes. The Elementary School Journal, 102(3), 225-238.

Pianta, R., \& Stuhlman, M. (2004). Teacher-child relationships and children's success in the first years of school. School Psychology, 33(3), 444458 
Pianta, R., Howes, C., Burchinal, M., Bryant, D., Clifford, R., Early, D., \& Barbarin, O. (2005). Features of pre-kindergarten programs, classrooms, and teachers: Do they predict observed classroom quality and child-teacher interactions? Applied Developmental Science, 9(3), 144-159.

Pianta, R. C., La Paro, K. M., \& Hamre, B. K. (2008). Classroom assessment scoring system: Pre-K. Paul Brookes Publishing.

Reeve, J. (2006). Teachers as facilitators: what autonomy-supportive teachers do and why their students benefit. The Elementary School Journal, 106(3), 225-236.

Ritz, M., Noltemeyer, A., Davis, D., \& Green, J. (2013). Behavior management in preschool classrooms: Insights revealed through systematic observation and interview. Psychology in the Schools, 51(2), 181-197.

Sherfinski, M. (2017). Culture matters: A comparative study of teachers' views of universal prekindergarten in two state regions. Early Child Development and Care

Snyder, P. A., Hemmeter, M. L., \& Fox, L. (2015). Supporting implementation of evidence-based practices through practice-based coaching. Topics in Early Childhood Special Education, 1-11.

Son, S. H. C., Kwon, K., Jeon, H. J., \& Hong, S. Y. (2013). Head start classrooms and children's school readiness benefit from teachers' qualifications and ongoing training. Child Youth Care Forum, 42, 525-553.

Strogilos, V., Avramidis, E., Voulagka, A., \& Tragoulia, E. (2018). Differentiated instruction for students with disabilities in early childhood co-taught classrooms: Types and quality of modifications. International Journal of Inclusive Education. https://doi.org/10.1080/13603116.2018.1466928

Sutherland, K. S., Conroy, M. A., Vo, A., \& Ladwig, C. (2014). Implementation integrity of practicebased coaching: Preliminary results from the BEST in CLASS efficacy trial. School Mental Health

Tsangaridou, N. (2017). Early childhood teachers' views about teaching physical education: Challenges and recommendations. Physical Education and Sport Pedagogy, 22(3), 283-300.
Vlachou, A., and A. Fyssa. 2016. Inclusion in Practice: Programme Practices in Mainstream Preschool Classrooms and associations with context and teacher characteristics. International Journal of Disability, Development and Education. DOI: 10.1080/1034912X.2016.1145629

Wakabayashi, T., Claxton, J., \& Smith, Jr., E. V., (2019). Validation of a revised observation-based assessment tool for children birth through kindergarten: The COR advantage. Journal of Psychoeducational Assessment, 1-22. 